\title{
The Effect of Wrestling Education on Some Physical and Motoric Parameters in High School Students
}

\author{
Ayça Genç ${ }^{1}$ \\ ${ }^{1}$ BartınUniversity, Faculty of Sport Sciences, Bartın, Turkey \\ Correspondence: Ayça Genç, Faculty of Sports Science Coaching Education Department, Bartin, Turkey. E-mail: \\ aycagenc@bartin.edu.tr
}

Received: June 15, 2019

Accepted: September 20, 2019

Online Published: March 9, 2020

doi:10.5539/ies.v13n4p100

URL: https://doi.org/10.5539/ies.v13n4p100

\begin{abstract}
The aim of this study is to examine the effect of wrestling education on some physical and motoric parameters in high school students. 42 volunteer men aged 15-17, who received regular wrestling training, participated in the study. In the study, after all, subjects were divided into 3 groups according to age groups, body weight, height, BMI, claw, back, leg strength, 10 and $30 \mathrm{~m}$ sprint, flexibility, anaerobic power, fat percentage, and body circumference measurements were taken. SPSS 20.0 program was used in the statistical analysis of the data obtained, the normality distribution of the data was determined by the Shapiro-Wilk test. Descriptive statistics, One Way ANOVA was used for normally distributed data and the level of significance was taken as $\mathrm{p}<0.05$. When the findings were examined, there was a significant difference between the age variable and BMI, 30m sprint, anaerobic power, shoulder and chest circumference $(\mathrm{p}<0.05)$, while there were no significant differences in height, weight, claw, back, leg strength, $10 \mathrm{~m}$ sprint, flexibility, fat percentage, waist, hip and femur values $(p>0.05)$. In conclusion, besides the effect of growth in the adolescent period in different age groups, it can be said that wrestling education has positive effects on BMI, $30 \mathrm{~m}$ sprint, anaerobic power, and some environmental measurements.
\end{abstract}

Keywords: high school student, wrestling education, male

\section{Introduction}

The adolescent period is a special and important period in which growth and development are the fastest and involves transition from childhood to adulthood (Pekcan, 2004). In individuals in the high school age group; features such as body composition, height, muscle mass, body fat percentage, strength, speed, flexibility, coordinative abilities constantly change (Çoknaz, 2017). It is supported by the literature that regular sports training has positive effects on physiological and psychological features (Günay et al., 2013). The regular exercise performed in this period; it has positive effects such as cardiovascular health, respiratory parameters, effective communication skills, strengthening of muscle, bone and joint structure, coping with stress, protection against diseases by providing positive effects on immunity (Çoknaz, 2017). In addition, while sports training from an early age positively affects the quality of life of the individual, it plays an important role in the emergence of talented athletes and determining the country's sports policy (Alic1 \& İri, 2015).

A significant increase in physical motor performance is observed with regular sports training in the 15-17 age group (Günay et al., 2018). Increasing the resistance to physical and physiological fatigue caused by static and dynamic forces without decreasing the efficiency of the individuals who are trained in sports is important in terms of the effective performance of the sport. Anaerobic loadings are important especially in sports education between the ages of 15-16 (Açak, 2001). Sports training performed in this period varies according to the branch applied. Individuals who received wrestling training are expected to develop muscular strength, rapid reaction time, neuromuscular coordination, static, dynamic balance, high anaerobic capacity and arm, leg and trunk muscles, and these features are important in terms of performance improvement in athletes training in wrestling (Alpay \& Hazar, 2006; Weineck, 1998). The wrestling branch develops largely due to body strength and it is seen that the results of the evaluations based on body weight criteria are among the strongest athletes in the wrestlers (Baykuş, 1989). In a study examining physical and physiological gains in wrestlers aged 15-17, it was found that there were significant differences in height, anaerobic power, FVC, reaction time, leg strength, push-ups, and shuttle test values in subjects after wrestling training during 9.5 months (Cicioğlu et al., 2007). 
Individuals who received wrestling training throughout the season are expected to increase their physical and motoric performance. In this study, it was aimed to examine the effect of wrestling education on some physical and motoric parameters in high school students.

\section{Methods}

This study included 42 competitor wrestlers aged 15-17, at the age of high school education (Table 1). Measurements were made at the beginning of the preparatory period. In addition, the volunteer approval form was taken from the wrestler students and the criteria specified in the Helsinki Declaration were respected.

\subsection{Bodyweight, Height, Body Mass Index (BMI) Measurements}

The subjects have been weighed in up to 20 -grams sensitive weighbridge with bare feet and shorts only. Length measurements have been taken with the Holtain slide calipers while the subjects were standing in upright position having the calipers that slide along the scale adjusted so that they can touch the heads and read with an accuracy of $1 \mathrm{~mm}$ in length. This net body weight was then used to calculate body mass index , BMI $(\mathrm{kg} / \mathrm{m} 2=$ Body weight $(\mathrm{kg}) /$ Length $\left(\mathrm{m}^{2}\right)$ (Inokuchi et al., 2006).

\subsection{Body Environmental Measurements}

Body environmental measurements of the wrestlers participating in the research were made with an anthropometric tape measure (Gulick meter) with precision measurement of $\pm 1 \mathrm{~mm}$ from the determined regions (Demirhan et al., 2019).

\subsection{Sprint Performance Tests (10-30M)}

The subjects were held ready at the exit point. When the subjects felt they were ready, they ran the distance (1-30 m) using maximal velocities. The time between start and end was determined by photocell (New Test 2000, Oulu, Finland). Tests were applied to subjects three times and the best performance value was analyzed (Demirhan et al., 2019).

\subsection{Anaerobic Power}

An anaerobic power calculation was calculated using Lewis Formula (Tamer, 2000; Fox et al., 1988). Three trials were given. The maximum value among the 3 readings was used to calculate the anaerobic power by the Lewis formula. A.P. $=\sqrt{ } 4.9 \times$ body weight $(\mathrm{kg}) \times \sqrt{ }$ high jump distance $(\mathrm{m})$

\subsection{Body Fat Ratio Measurements}

Body Fat ratios of athletes were defined by determining the chest, triceps, subscapular, suprailiac, abdomen and thigh skinfold thickness and by measuring the fat percentage calculated using the following formula Percentage of fat $=(\Sigma$ skin folds $\times 0.097) 3.64$ (Özer, 1993).

\subsection{Flexibility Measurements}

Flexibility values of the subjects were measured with the help of the Lafayette brand test bench, that length is 35 $\mathrm{cm}$, width is $45 \mathrm{~cm}$ and height is $32 \mathrm{~cm}$. It was made to reach forward from the trunk without bending the knees and trying to reach the farthest point. The best result was recorded in $\mathrm{cm}$ by doing two reps (Sökmen et al., 2013).

\subsection{Force Measurements}

Paw forces of the subjects were measured using a hand dynamometer. An electronic dynamometer capable of measuring between 20-300 kg was used for back and leg force measurements. Two measurements were made for each subject and the best value on the indicator was recorded in kg (Poyraz et al., 2015).

\subsection{Statistical Evaluation}

SPSS 20.0 program was used in the statistical analysis of the data obtained, the normality distribution of the data was determined by the Shapiro-Wilk test. Descriptive statistics, One Way ANOVA was used for normally distributed data and the level of significance was taken as $p<0.05$. 


\section{Results}

Table 1. Comparison of physical and motoric parameters of individuals wrestling training according to age variable

\begin{tabular}{|c|c|c|c|c|c|c|c|}
\hline & & Sum of squares & $\mathrm{sd}$ & Average of squares & $\mathrm{f}$ & $\mathrm{p}$ & Significant difference \\
\hline \multirow{3}{*}{ Weight } & Between Groups & 302.89 & 2 & 151.44 & \multirow{3}{*}{2.383} & \multirow{3}{*}{.11} & \multirow{3}{*}{-} \\
\hline & in-groups & 2541.87 & 40 & 63.54 & & & \\
\hline & Total & 2844.76 & 42 & & & & \\
\hline \multirow{3}{*}{ Height } & Between Groups & 101.05 & 2 & 50.52 & \multirow{3}{*}{1.619} & \multirow{3}{*}{.21} & \multirow{3}{*}{-} \\
\hline & in-groups & 1248.11 & 40 & 31.20 & & & \\
\hline & Total & 1349.16 & 42 & & & & \\
\hline \multirow{3}{*}{ VKİ } & Between Groups & 88.71 & 2 & 44.35 & \multirow{3}{*}{8.767} & \multirow{3}{*}{.00} & $15-16 y$ \\
\hline & in-groups & 202.37 & 40 & 5.05 & & & $15-17 y$ \\
\hline & Total & 291.08 & 42 & & & & $16-17 \mathrm{y}$ \\
\hline \multirow{3}{*}{ Claw right Between } & Between Groups & 64.70 & 2 & 32.31 & \multirow{3}{*}{0.455} & \multirow{3}{*}{0.64} & \multirow{3}{*}{ - } \\
\hline & in-groups & 2841.57 & 40 & 71.03 & & & \\
\hline & Total & 2906.27 & 42 & & & & \\
\hline \multirow{3}{*}{ Claw left } & Between Groups & 140.63 & 2 & 70.31 & \multirow{3}{*}{1.19} & \multirow{3}{*}{.31} & \multirow{3}{*}{-} \\
\hline & in-groups & 2345.82 & 40 & 58.64 & & & \\
\hline & Total & 2486.46 & 42 & & & & \\
\hline \multirow{3}{*}{ Back force } & Between Groups & 1459.27 & 2 & 729.64 & \multirow{3}{*}{2.01} & & \\
\hline & in-groups & 14507.79 & 40 & 362.69 & & .18 & - \\
\hline & Total & 15967.07 & 42 & & & & \\
\hline & Between Groups & 2646.26 & 2 & 1323.13 & & & \\
\hline Leg force & in-groups & 20618.52 & 40 & 515.46 & 2.56 & .09 & - \\
\hline & Total & 23264.79 & 42 & & & & \\
\hline & Between Groups & .198 & 2 & .099 & & & \\
\hline $10 \mathrm{~m}$ sprint & in-groups & 1.70 & 40 & .043 & 2.32 & .11 & - \\
\hline & Total & 1.90 & 42 & & & & \\
\hline & Between Groups & 1.013 & 2 & .507 & & & \\
\hline $30 \mathrm{~m}$ sprint & in-groups & 5.17 & 40 & .129 & 3.91 & .03 & $15-16 y$ \\
\hline & Total & 6.18 & 42 & & & & \\
\hline & Between Groups & 1.77 & 2 & .88 & & & \\
\hline Percentage of fat & in-groups & 40.96 & 40 & 1.02 & .86 & .43 & - \\
\hline & Total & 42.73 & 42 & & & & \\
\hline & Between Groups & 4.90 & 2 & 2.45 & & & \\
\hline Flexibility & in-groups & 720.71 & 40 & 18.01 & .136 & .87 & - \\
\hline & Total & 725.62 & 42 & & & & \\
\hline & Between Groups & 2723.84 & 2 & 1361.92 & & & $15-16 y$ \\
\hline Anaerobic power & in-groups & 5578.76 & 40 & 139.46 & 9.76 & .00 & $15-17 y$ \\
\hline & Total & 8302.60 & 42 & & & & $16-17 y$ \\
\hline & Between Groups & 376.91 & 2 & 188.45 & & & $15-16 y$ \\
\hline Shoulder circumference & in-groups & 1176.55 & 40 & 29.41 & 6.40 & .00 & $15-17 y$ \\
\hline & Total & 1553.46 & 42 & & & & $16-17 y$ \\
\hline & Between Groups & 87.04 & 2 & 43.52 & & & \\
\hline Neck circumference & in-groups & 3085.60 & 40 & 77.14 & .564 & .57 & - \\
\hline & Total & 3172.65 & 42 & & & & \\
\hline & Between Groups & 363.21 & 2 & 181.60 & & & \\
\hline Chest circumference & in-groups & 2194.35 & 40 & 54.85 & 3.31 & .04 & $15-17 y$ \\
\hline & Total & 2557.57 & 42 & & & & \\
\hline & Between Groups & 47.37 & 2 & 23.68 & & & \\
\hline Waist circumference & in-groups & 1049.32 & 40 & 26.23 & .903 & .41 & - \\
\hline & Total & 1096.69 & 42 & & & & \\
\hline
\end{tabular}




\begin{tabular}{|c|c|c|c|c|c|c|c|}
\hline \multirow{3}{*}{ Hip circumference } & Between Groups & 42.74 & 2 & 21.37 & \multirow{3}{*}{.697} & \multirow{3}{*}{.51} & \multirow{3}{*}{-} \\
\hline & in-groups & 1226.52 & 40 & 30.66 & & & \\
\hline & Total & 1269.26 & 42 & & & & \\
\hline \multirow{3}{*}{ Femur circumference } & Between Groups & 116.63 & 2 & 58.31 & \multirow{3}{*}{2.77} & \multirow{3}{*}{.08} & \multirow{3}{*}{ - } \\
\hline & İn-groups & 842.05 & 40 & 21.05 & & & \\
\hline & Total & 958.68 & 42 & & & & \\
\hline
\end{tabular}

When Table 1 is examined, there is no significant difference between age variable and height, weight, claw, back, leg strength, $10 \mathrm{~m}$ sprint, flexibility, fat percentage, waist, hip, and femur values ( $p>0.05)$, however, there was a significant difference between the groups in terms of BMI, 30m sprint, anaerobic power, shoulder and chest circumference $(\mathrm{p}<0.05)$.

\section{Discussion}

It is expected that regular wrestling exercise is to lead to changes in the physical and motoric characteristics of children of developmental age. In the study, it was observed that there was no significant difference between the age variable of the groups and their height and body weight. Unlike our study, Cicioğlu et al. (2007) found a significant relationship between the age variable and body weight and height. It is observed in Table 1 that there is a significant difference between BMI and age variables between all groups. For age, a positive increase in BMI is observed. Aslan et al. (2013) found that BMI averages of athletes aged 13-15 were $22.1 \pm 4.0 \mathrm{~kg} / \mathrm{m} 2$ and increased with age. Bayraktar et al. (2012) according to the research findings, BMI values increased in parallel with the increase in age. Claw force is important in terms of the wrestling branch. There are parallel and opposite studies in our literature. In the study, no significant difference was found between the right and left paw force and the age variable. Gökdemir et al. (2000) have found positive developments in right and left paw forces as a result of 8 weeks of training in wrestlers aged 16-17, in another study, there were differences between the right and left paw forces of the wrestlers in parallel with exercise training, in another study, he suggested that different sports training caused changes in claw force (Ziyagil et al., 1996; Alıcı \& İri, 2015). It was determined that there was no significant difference between the groups in terms of back and leg strength values.Aydos et al. (2004) found the back force average of individuals who received wrestling training as $94.9 \pm 21.44 \mathrm{~kg}$, In another study, it was found that there were significant differences in the back and leg strength between the groups with and without sports training (Polat et al., 2009). Strength training has positive effects on back and leg strength. The absence of significant differences between the groups according to the age variable may be an indication of insufficient strength training. In the study, it was found that there was no significant difference between the age variable and $10 \mathrm{~m}$ sprint, but there was a significant difference in the performance of the $30 \mathrm{~m}$ sprint between the 15-16 age group. When the literature had analyzed, it has been determined that exercise training that is carried out regularly for 12 weeks does not cause any change in sprint performance in the wrestling branch. It was thought that this difference between the groups is due to the increase in sprint ability with age. No statistically significant difference was observed between the age variable and fat percentage and flexibility values. When the literature had analyzed, Aslan et al. (2013) reported that the percentage of fats of the wrestlers in the age range of $13-15$ is $12.1 \pm 6.1 \%$, in another study, the average of fat percentage of wrestlers with the average age of 16 is $6.71 \pm 1.32$ (Ziyagil et al., 1996). Bayraktar et al., (2012) values are decreasing in parallel with the increase in age except for 13 years and it is observed that it increases after 17 years of age. Flexibility is of great importance in wrestling while applying techniques, high flexibility contributes to making the movement perfect.According to Petrow, the best flexibility can be developed between the ages of 12-14 (Petrow, 1987). In this age group, flexibility is expected to have similar characteristics, and our study supported this. In the study, significant differences were observed in all age groups in terms of anaerobic power performance.Anaerobic power and capacity; performance determining criteria for high intensity or maximal exercises in a short time. It has been determined that anaerobic power is related to age, body weight and most importantly lean body mass, body weight positively affects the strength and anaerobic power. Kürkçü et al. (2009) determined the anaerobic power levels of children 12-13 years of age wrestling training as $107.79 \pm 11.68$ $(\mathrm{kg} / \mathrm{m} / \mathrm{sec})$. Cicioğlu et al. (2007) determined that the pre-season and post-season changes of the wrestlers in the $15-17$ age group were in the range of $102.26 \pm 13.57$ to $117.94 \pm 13.84 \mathrm{kgm} / \mathrm{sec}$, respectively. It has been determined that wrestlers' lean body masses and body fat percentages are effective in anaerobic performance and leg and back strength (Şenel et al., 2009). Muscle strength, muscular endurance, and anaerobic capacity are the most important variables in individuals who received Greco-Roman wrestling training and it is important to develop these variables to be successful (Nikooie et al., 2017). In a study of wrestlers, some variables such as body weight, leg-arm muscle mass were found to play a role in anaerobic performance values taken from the 
lower extremities (Erkılıç \& Şenel, 2019). In our study, it was found that there was no significant relationship between the age variable and the circumference of the neck, waist, hip, and femur. While there was a significant difference between the groups in all age categories around the shoulder, there was only a significant difference in the chest area between the ages of 15-17. Our study, Cicioğlu et al. (2007) Measurements carried out environmentally by 15-17 age star national team athletes have parallel results. In another study of anaerobic power; biceps, chest, thigh and abdominal circumference, wrist, elbow, knee and trochanter diameters, shoulder width, sitting height, handgrip strength, and fat percentage were found significantly related (Ağaoğlu et al., 2001). Overall, to achieve high-level wrestling performance, training should be directed to develop anaerobic power and capacity, aerobic power, maximal dynamic and isometric strength, explosive strength, and strength endurance.

Wrestling education taken in order to achieve high efficiency should be towards developing anaerobic power and capacity, aerobic power, maximum dynamic, and isometric power, explosive power, flexibility, and endurance. (Helmi et al., 2017).

\section{Conclusion}

As a result, individuals with wrestling training throughout the season are expected to increase their physical and motoric performance. Growth in the age range of 15-17 is very fast in certain parameters and changes can be observed in a short time. Undoubtedly, exercise education in the age of growth has positive effects on the development of children. In the light of the information obtained in our study, regular wrestling training was found to have positive effects on BMI, $30 \mathrm{~m}$ sprint, anaerobic power, and some environmental measurements. In future studies, the study can be developed by considering different exercise education, age, and gender.

\section{References}

Açak, M., \& Açak, M. (2001). Güreş Öğreniyorum. Malatya, Kubbe Yayıncılık.

Ağaoğlu, S., İmamoğlu, O., Kishali, N. F., \& Çebi, M. (2001). Türk Erkek Milli Judo Takım Sporcularının Belirli Fizyolojik ve Antropometrik Özelliklerinin İncelenmesi. Beden Eğitimi ve Spor Bilimleri Dergisi, 1(3), 59-67.

Alıcı, Ö., \& İri, R. (2015). 13-15 yaş arası güreşçiler hentbolcular ve sedanterlerin bazı fiziksel ve fizyolojik parametrelerinin karşılaştırılması. International Journal of Human Science, 12(1), 1070-1081. https://doi.org/10.14687/ijhs.v12i1.3117

Alpay, B., \& Hazar, S. (2006). Türkiye Serbest Güeş A milli Takımı İle Üniversite Güreş Takımı Güreşçilerinin Bazı Solunum ve Dolaşım Parametrelerinin Karşılaştırılması. Beden Eğitimi ve Spor Bilimleri Dergisi, 8(3).

Aslan, C. S., Karakollukçu, M., Gül, M., \& Fişne, M. (2013). 13-15 Yaş Güreşçilerin Fiziksel Motorik Özellikleri. Spor Hekimliği Dergisi, 48, 1-7.

Aydos, L., Pepe, H., \& Karakuş, H. (2004). Bazı Takım ve Ferdi Sporlarda Rölatif Kuvvet Değerlerinin Araştırılması. Gazi Üniversitesi Kırşehir Eğitim Fakültesi, 5(2), 305-315.

Baykuş, S. (1989). The Analysis of Physiological Characteristics of 17-20 years old the Turkish National Free Style and Greco-romen Espoir Teams Wrestlers (Unpublished master thesis). Middle East Technical University.

Bayraktar, I., Deliceoğlu, G., Tekelioğlu, A., Hazır, M., Kabak, B., \& Ufuk, P. (2012). Erkek Adölesan Güreşçilerin Antropometrik Profil Normları. Uluslararası Hakemli Akademik Sağllk ve Tip Bilimleri Dergisi, 2(2), 118-127.

Cicioğlu, İ., Kürkçü, R., Eroğlu, H., \& Yüksek, S. (2007). 15-17 Yaş Grubu Güreşçilerin Fiziksel ve Fizyolojik Özelliklerinin Sezonsal Değişimi. Spormetre Beden Eğitimi ve Spor Bilimleri Dergisi, 4, 151-156. https://doi.org/10.1501/Sporm_0000000085

Çoknaz, H. (2017). Psikomotor Gelişim. Ankara: Gazi Kitabevi.

Demirhan, B., Abdurahmanova, Türkmen M., \& Canuzakov, K. (2019). Determination of some physical properties of u-23 soccer players. Ovidius University Annals, Series Physical Education \& Sport/Science, Movement \& Health, 19(2).

Erk1lı̧, A. O., \& Şenel, Ö. (2019). Determination of Relationships between Body Composition, Anaerobic Performance and Balance in Wrestlers. International Journal of Sports Culture and Science, 7(4), 1-10. https://doi.org/10.14486/ IntJSCS.2019.581

Fox, E. L., Bowers, R. W., \& Foss, M. L. (1998). The Physiological Basis of Physical Education and Athletics 
(4th ed,). Saunders College Publishing, Philadelphia.

Gökdemir, K. (2000). Güreş Antrenmanının Bilimsel Temelleri. Ankara: Poyraz Ofset.

Günay, M., Cicioğlu, İ., Şıktar, E., \& Şıktar, E. (2018). Çocuk, Kadın, Yaşlı ve Özel Gruplarda Egzersiz. Ankara: Gazi Kitabevi.

Günay, M., Tamer, K., \& Cicioğlu, İ. (2013). Spor Fizyolojisi ve Performans Ölçümü. Ankara: Gazi Kitabevi.

Helmi, C., Yassine, N., Raja, B., Bessem, M., Emerson, F., Ursula, J., \& Younes, H. (2017). Physical and Physiological Attributes of Wrestlers: An Update. The Journal of Strength \& Conditioning Research, 1(5), 1411-1442. https://doi.org/10.1519/JSC.000000000001738

Inokuchi, M., Hasegawa, T., Anzo, M., \& Matsuo, N. (2006). Standardized centile curves of body mass index for Japanese children and adolescents based on the 1978-1981 national survey data. Annals of human biology, 33(4), 444-453. https://doi.org/10.1080/03014460600802353

Kürkçü, R., Ersoy, A., \& Aydos, L. (2009). Güreşçilere uygulanan 12 haftalık antrenman programının bazı fiziksel ve fizyolojik özellikler üzerine etkisi. e-Journal of New World Sciences Academy Sports Sciences, 4, 313-321.

Nikooie, R., Cheraghi, M., \& Mohamadipour, F. (2017). Physiological determinants of wrestling success in elite Iranian senior and junior Greco-Roman wrestlers. The Journal of Sports Medicine and Physical Fitness, 57(3), 219-226. https://doi.org/ 10.23736/S0022-4707.16.06017-5

Özer, M. (1993). Antropometri: Sporda Morfolojik Planlama. İstanbul: Kazancı Matbaacılık.

Pekcan, G. (2004). Adolesan Döneminde Beslenme. Klinik Çocuk Forumu, 4(1), 38-47.

Petrov, R. (1978). Perfertionnenement de la maitrise technico-tactigue de lutteur medicinai fizkultura. Sofia, 18, 21.

Polat, Y., Çınar, V., Savucu, Y., \& Polat, M. (2009). 16 Yaş Gençlerin Fiziksel Uygunluk Düzeylerinin İncelenmesi. e-Journal of New World Sciences Academy Sport Sciences, 4(1), 1-9.

Poyraz, A., Baş, O., Ocak, Y., Yıldııım, İ., \& Tortop, Y. (2015). Avrupa badminton takım şampiyonası'na katılan sporcuların bazı fiziksel ve fizyolojik özelliklerinin karşılaştırılması. Spor ve Performans Araştırmaları Dergisi, 6(2), 121-133. https://doi.org/10.17155/spd.56155

Şenel, Ö., Taş, M., Harmancı, H., Akyüz, M., Özkan, A., \& Zorba, E. (2009). Güreşçilerde Vücut Kompoziyonu anaerobik performans, bacak ve sırt kuvveti arasındaki ilişkinin belirlenmesi. Gazi Beden Eğitimi ve Spor Bilimleri Dergisi, 2, 13-22.

Sökmen, T., \& Arslanoğlu, E. (2013). Judo teknik antrenmanı ve oyunların 8-10 yaş grubu erkek çocukların fiziksel gelişim düzeyleri üzerine etkisi. Spormetre Beden Eğitimi ve Spor Bilimleri Dergisi, 11(2), 73-79. https://doi.org/10.1501/Sporm_0000000241

Tamer, K. (2000). Sporda Fiziksel-Fizyolojik Performansin Ölçülmesi ve Değerlendirilmesi. Ankara: Bağırgan Yayınevi.

Weineck, J. (1998). Sporda İşlevsel Anatomi. Bağırgan Yayımevi, Çev. A. Semra Elmacı, Ankara.

Ziyagil, M. A., Zorba, E., Kutlu, M., Tamer, K., \& Torun, K., (1996). Bir Yıllık Antrenmanın Yıldızlar Kategorisindeki Serbest Stil Türk Milli Takım Güreşçilerinin Vücut Kompozisyonu ve Fizyolojik Özellikleri Üzerine Etkisi. Gazi Üniversitesi Beden Eğitimi ve Spor Bilimleri Dergisi, 1(4).

\section{Copyrights}

Copyright for this article is retained by the author(s), with first publication rights granted to the journal.

This is an open-access article distributed under the terms and conditions of the Creative Commons Attribution license (http://creativecommons.org/licenses/by/4.0/). 